\title{
Call for Papers for Special Issue of Pneuma on the Global covid-19 Pandemic
}

The co-editors of Pneuma: The Journal of the Society for Pentecostal Studies are pleased to announce a special edition on the global coviD-19 pandemic. We are soliciting essays on pentecostal interpretations and analyses of the impact of the novel coronavirus on communities, economies, politics, homiletics, social ethics, cultural resistance, biblical hermeneutics, religion and science, church management, social justice, pentecostal theologies, and so on. The focus of any essay in each of these areas should be on Pentecostals and pentecostal communities in the context of their larger lifeworld. We also encourage historians to submit essays on Pentecostals' responses to previous epidemics and pandemics. Sociologists and anthropologists are invited to submit analyses of the impact of the pandemic on pentecostal communities, churches, or organizations.

As the preeminent journal dedicated to studying global Pentecostal movements and now proposing a special issue on the worldwide corona pandemic, we especially encourage essays from all corners of the globe. All essays should be sent to Pneuma using the journal electronic essay submission format no later than Thursday, December 31, 2020. All essays will go through the journal's rigorous peer review, and those that make the cut will be published in the second edition of 2021.

Online Submission: Pneuma uses Editorial Manager, a web-based submission and peer review tracking system. All manuscripts should therefore be submitted online at www.editorialmanager.com/pneuma.

Please make sure to consult the Instructions for Authors prior to submission to ensure your submission is formatted correctly. For any questions, please contact the Editorial Office at the email links below.

Nimi Wariboko: nimiwari@bu.edu

L. William Oliverio, Jr.: bill.oliverio@northwestu.edu 